\title{
CRIME AND PUNISHMENT IN IGBO CUSTOMARY LAW: THE CHALLENGE OF NIGERIAN CRIMINAL JURISPRUDENCE
}

\author{
Ikenga K. E. Oraegbunam
}

\begin{abstract}
Every society has its own means of controlling the social behaviour of its citizens in order to reach its desired goals. The importance of the legal framework in this regard cannot be gainsaid. Thus, law provides, among other things, the penal technique by which those who are found guilty of acts prohibited by the society are punished. The Igbo society of Nigeria has in its body of customary laws a rich penal system. Though largely unwritten, prior to the advent of the British, this legal regime integrated the Igbo society unto its development. The Nigerian post-independence era, however, presented a veritable antipathy to and outright abolition of the customary criminal laws including that of the Igbo. Influenced by the received English system, its negative attitude to spiritualism in which most of the customary practices are immersed gives an added fillip to this disregard. But in their private lives and in the hinterland, people surely return to their primordial convictions. There is therefore the need to evolve a safe compromise that will preserve the baby after throwing away the bath water.
\end{abstract}

\section{Introduction}

Over and over again, the two concepts of "crime" and "punishment" have constituted themselves into a whole lump of siamese twins. Often, one can neither speak of 'crime' without 'punishment' nor 'punishment' without 'crime'. No wonder, Okonkwo, a doyen of Criminal Law in Nigeria, sees punishment simpliciter as the object of Criminal Law ${ }^{1}$. In criminal law textbooks in Nigeria and beyond, a crime or offence is said to have been created only when the attendant punishment is also stipulated. In the 1999 Constitution of the Federal Republic of Nigeria, which is the supreme law of the land, one cannot be guilty of an offence unless the punishment to that offence is also prescribed by a written law $^{2}$. Again, one cannot be criminally and penally responsible for an act that did not constitute a crime at the time of its commission ${ }^{3}$. All these 
illustrations, carefully articulated in the Latin maxim "nulla poena sine crimen" clearly demonstrate the intricate connection between crime and punishment. What is more, this conceptual and mutual intimacy between crime and punishment has also expressed itself in the adoption of the concepts by many authors for the title of their literary works ${ }^{4}$.

Besides, the existence of crime and punishment is a reality of human existence. Just as crime and criminal activities are co-eval with man breeding disharmony in his society and the natural order in general, punishment is equally co-existent with man from time immemorial making it, as it were, the tool for prevention of crime and for other reasons ${ }^{5}$. This paper seeks to examine the jurisprudence of crime and punishment in traditional Igbo society. It considers the following questions: what are crimes in Igbo traditional society? What types of punishment can attach to the commissions of crimes? What are the aims of these punishments? How are crimes detected and what judicial methods are used in administration of criminal justice? Have crimes and punishment any relationship with Igbo traditional religion? In other words, what are the characteristics of traditional Igbo society and its worldview visà-vis the idea of crime and punishment? And what is the present status of customary criminal law in the light of the prevailing Nigerian legal system? Attempts to these questions and more would be our guide in this discourse.

It may be appropriate to remark from the onset that the present writer is not unaware of the fact that the Igbo society of today is a hybrid. It is therefore not intendment of this paper to resuscitate an Igbo past some of which elements are far from palatable. Besides, such an exercise is neither possible nor even desirable. However, it has been observed that in spite of modernization and influx of western ideas, certain primordial convictions yet endure in the modern Igbo man. And in terms of historical importance, it may be congenial to undertake this study for the purpose of reshaping our present and future. 


\section{Igbo Society}

The Igbo people constitute one of the major tribal groups in Nigeria today. According to the colonial geography, the Igbo occupy mainly the eastern part of the country. They are today found in high concentration in Anambra, Abia, Enugu, Ebonyi and Imo states of Nigeria. There are also large Igbo populations in Delta and River states. Igbo people are a very immigrant race. They are in large numbers resident in Northern Nigeria and in old Ogoja, Calabari, Benin, and Lagos. Too, Igbo migrants trooped out to the Cameroons, Gabon, Congo Brazzaville, Equatorial Guinea, and recently to all parts of ECOWAS sub-region and South Africa. And apart from the trans-Atlantic slave trade that populated Europe and the Americas with good number of Igbo elements, the $20^{\text {th }}$ and $21^{\text {st }}$ centuries have also witnessed an unprecedented influx of the people into the western world perhaps in search of the greener pastures. As a result of cultural diffusion experienced both by the home front due to colonial incursion and neocolonism and by the Diaspora who presently are in serious romance with the western culture, much of the traditional practices have undergone serious modification. This is certainly consequent upon Igbo receptivity and amenability to change $^{6}$. Hence, the Igbo traditional socio-political institutions notably communalism, democracy and religion have been drastically altered and modulated by imperialist incursion and Igbo access to western education, culture, Christianity and capitalism. City consciousness and urbanity have become integral components of the Igbo society. Onitsha, Aba, Enugu, Owerri, Umuahia, Awka, Nnewi, Agbor, Asaba and Abakaliki are fast growing Igbo cities populated, as it were, by hitherto rural dwellers. Another stamp of westernism is manifested in physical structures such as roads, streets, electricity, hospitals, building architecture, house furniture and home facilities, and so on.

Yet, in spite of the above foreign influence and more, certain traditional practices are quite resilient. In the hinterland, some traditional Igbo communities live in dispersed settlements. The Igbo village, which is a small face-to-face society, is still easily recognizable. A number of closely clustered compounds and families form the Igbo village and several villages make up towns. Again, in spite of the modern alteration, the Igbo traditional political 
institutions that are designed to combine popular participation with weighing for experience and ability are still in tandem with the extended family sociology. The family head, the elders, the age grade, secret societies etc play a key role in this socio-political structure. Economically, the Igbos in the urban areas are traders and craftsmen. In the rural areas, they are largely farmers. In modern times, a good number are professionals in the areas of law, science, medicine, etc. The people embrace Christianity in huge numbers. However, that may be, much of Igbo traditional living and attitudes is still conditioned by its traditional worldview. It may thus be necessary to delineate, albeit briefly, the key elements of traditional Igbo worldview which discussion may be helpful in the understanding of crime and punishment in traditional Igbo society.

\section{Traditional Igbo Worldview}

It has often been argued that one's worldview constitutes the Archimedean point from which one operates. A worldview represents the sedimentation of a peoples' conception of the way things are and how they should be. No wonder Kraft calls it a 'control Box' that governs the application of the people's conceptualization of their relationships to reality ${ }^{7}$. In the same way, Okafor sees a people's worldview as "the concepts of the "basic notions underlying their cultural, religious and social activities" Onuoha is of the same view when he writes that a worldview comprises "a set of values, concepts, attitudes and images which guide man's perception and interpretation of facts and events ${ }^{9}$." Simply put, a worldview of a people is just the way that particular people view reality, which way according to Oguejiofor, is always "context dependent". 10

The Igbo people of Nigeria also have their worldview, which exercises a no mean influence on the way they act, move and have their being. Nwala refers to Igbo worldview as the Igbo complex of beliefs, habits, laws, customs and tradition of reality. ${ }^{11}$ It may at this point be germane to adumbrate some elements of Igbo worldview and delineate their practical influence on Igbo life generally.

One of the results of several studies on Igbo anthropology, religion and philosophy, in spite of few dissenting voices, is a widespread belief in supreme and unique God, Chukwu (The Great 
Spirit), Chineke (The Creator Spirit), Osebuluuwa (The Lord who upholds the world), Ezechitoke (The Spirit King Creator), Okasiakasi (The Greatest Being), etc are some of the names with which this God is addressed. Arinze has other characteristics peculiar to this Supreme Being: "No one equals him in power. He knows everything. He is altogether a good and merciful God and does harm to no one. He sends rain and especially children and it is from Him that each individual derives his personal 'chi' ${ }^{12}$

Furthermore, apart from belief in some lesser spirits, some good, others bad, the traditional Igbo also usually go through the ancestors. For the Igbo man, life is not utter extinction. His dead relatives continue communion and communication with him after death. These dead relatives have the power to influence, help or inflict injury and pains on those relations physically alive depending on whether or not their funeral rites are performed. ${ }^{13}$ These unseen ancestors are part of the particular Igbo family who are often invited to the family meals. According to Parrinder, the ancestors "are felt to be present, watching over the household, directly concerned in all the affairs of the family properly, giving abundant harvest and fertility". 14 This may be why they are referred to as "living dead" often expressed, as it were, in the institution of the masquerade cult. $^{15}$

Another important element of Igbo worldview is the manifest anthropocentricism that it often exudes. This is the view that man occupies the central position in any meaningful human activity including religion. Writing about African worldview generally, Metuh holds that "everything else seems to get its bearing and significance from the position, meaning and end of man". ${ }^{16}$ In Igbo world, there is of course recognition and respect for innumerable divinities but the relevance of all these is very much subject to their effect on man. ${ }^{17}$ Thus the Igbo man believes that all these divinities exist to serve him better his lot. He has a functional or pragmatic approach to these deities. This explains why a typical Igbo man can ceremoniously break his Ikenga (a cultic object of success and achievement) into two should it fail to perform. Hence, Oguejiofor observes that "the anthropocentricity of African (Igbo) traditional religion is one factor which explains the multiplicity of divinities in African pantheon" 18 as each divinity is intended to secure the order, 
regularity, and predictability of specific areas of man and his community.

But it appears this inordinate man-centered humanism is grounded on the "life-affirming" character of Igbo worldview often celebrated in rituals, festivals and ceremonies. Thus, vitalogy ${ }^{19}$, which Nkemnkia sees as basic philosophy of the African, applies so much to the Igbo. He esteems life, values it, celebrates it and does anything to protect it. There is hardly any room for martyrdom. The idea of this affirmation for life is littered in many an Igbo names, proverbs, songs, folk tales, etc. ${ }^{20}$ The Igbo sees life as an eternal stream, a process in which everyone is meant to pass on life. This is why marriage in traditional Igbo is highly esteemed especially for procreation of life. Thus, infertility, childlessness and celibacy are always shunned while divorce or polygamy is always considered as a consequence. In core Igbo sensibility, marriage is regarded as consummated only when the first man is delivered. ${ }^{21}$ Sequel to this Igbo predilection for life is its "this- worldly" nature. The life that the average Igbo man seeks is this earthly life and this is perhaps why there is a widespread belief in reincarnation, a process by which a man will after death come back to this earthly life. Thus, the idea of worshiping for the purpose of obtaining a better hereafter does not fit properly into the Igbo worldview in which the present world is in fact the highest good. Thus, the determination to cling to this life and the phenomenon of reincarnation as a reward for a good life lends credence to this view.

Further, the traditional Igbo views reality in a noncompartmentalized manner. His political, social, economic, cultural, moral and religious aspects of life form a continuum. Everything seems to have a deeply religious substructure mostly in order to enhance human life hic et nunc. It is this idea that informs the traditional Igbo legal system.

\section{Fundamentals of Traditional Igbo Legal System}

The traditional Igbo criminal jurisprudence is situated within the entire gamut of a legal system. The idea of a legal system itself implies the notion, or more concretely, the knowledge of a consummate whole of the institutions that have to do with or that pertains to law in a particular society. It therefore involves a 
consideration of the totality of all the various aspects of legal institutions and administration of justice in that society. No doubt, this consists in the entire trajectory of law making, administration, and enforcement. Thus, the traditional Igbo legal system may be considered along these parameters.

Enveloped in a socio-religious worldview, the structure of the justice system is built on the eternal goals and the social destiny of the Igbo person. In Igbo enclave, law (iwu) generally is geared towards the maintenance of spiritual and social harmony. From these socio-spiritual objectives, it becomes easy for one to decipher the respective sources of Igbo laws. It may therefore be appropriate to consider these sources and adumbrate the basic elements of Igbo legal system.

There is no gainsaying that laws in the traditional Igbo society are not codified. In spite of the various efforts of some contemporary Igbo scholars ${ }^{22}$ to put in a manual or code form the customary laws of Igbo people, yet such efforts are mere attempts aimed at modeling an oral-based culture after a high literary pattern of the English system. It looks like trying to put a square peg in a round hole. No doubt, a lot of values would be lost in such a mimic of a legal pigeonhole and straightjacket. The better description of the Igbo laws therefore would remain that they are unwritten, though quite comprehensive and acceptable. Be that as it may, the Igbos are quite aware that the laws that regulate and govern their lives and attitudes have an ordered hierarchy and derive from multifarious sources.

\section{Nature, Sources and Hierarchy of Igbo Laws}

\section{Divine Laws}

Topmost in the hierarchy of Igbo laws are the divine laws. 'Divine' means pertaining to God, originating from God, tending towards God. Green recognizes the divine laws in her classification of Igbo laws:

Legal rules are of two main classes and are recognized as such. There are those which might be called ordinary human laws and those whose breach is held to be not 
only illegal but also an offence against a supernatural power, and particularly against 'Ala'... ${ }^{23}$

The latter of the two categories alone is what we refer to as divine laws which violation is not only against society but also more directly against the supernatural. Certain remarkable features are characteristics of this set of laws. Firstly, they are not made by man and yet seem to have been written in the hearts of the Igbo ab ovo. They are more popularly referred to as part of the 'omenala' (custom). According to Okafor, "this apparent inability to trace these laws to any historical source or to any source whatsoever brings to the fore the other side of the divine law as the natural law" 24 which issue we shall consider anon. Secondly, heavy penalties attach to the breach of divine laws. As the offences are mainly against God, the creator of the universe, they are regarded as heinous and thus attract heavy punishments issuing as it were from the divine authority. We shall later see some of these penalties. Thirdly, the divine nature of these laws which breach is regarded as abomination ( $n s o, a r u$ ) is further demonstrated by the fact that it is only the supernatural tribune or court of justice that can assume jurisdiction in matters connected therewith. Fourthly, the Igbos believe that no violation of divine laws would go unpunished. The offenders must inevitably be punished either during their lifetime, or at the end of it, or even during their next life cycle. Thus, the divine laws are quite fundamental. Aimed at protecting the lives of the individuals in the community, and to safeguard the basic moral principles of the people, the divine laws guide and direct the society in its efforts to maintain its rapport with the spiritual community of the spirit world. This is not difficult to see as the Igbo natural religion permeates every facet of the Igbo life and engulfs their field of law.

As we insinuated above, there is a sense in which the Igbo divine laws can be described as natural laws. We are however 
not oblivious of the fact that the concept of 'natural law' had occasioned a heated up debate which, over the centuries, swept across the western world perhaps as a result of the misconception and misapplication of the word 'nature' in relation to laws. ${ }^{25}$ It may be germane to spend a little thought on the expression 'natural law' before relating it to the Igbo divine laws. The word 'nature' had acquired multifarious connotations, but in spite of this, it seems that its Latin etymology may be quite illustrative. Deriving from the Latin participle 'natus-a-um, meaning 'born' which gives rise to the form of the verb 'nascive' meaning to be born'. The idea of the 'nature' of things suggests what the things are born for, what they originated to do, or what they exist to accomplish. Hence, natural law is a unique law that is better understood when split into 'moral law' and 'physical law'. Natural law becomes moral law when it applies to man as a rational and moral being. In its physical aspect, natural law, or better still, law of nature applies to other animate, and inanimate bodies. As a moral law, natural law governs man by suasion, and as a physical law, by necessitation. It is good to note that the dispute over the idea of natural law is not in relation to its application as physical law but rather as moral law. As an Eternal law, the natural law is the ordinance of Divine Wisdom by which the entire creatures are governed. Being latent, man is able to discover it only through the operations of his reasons. As a free being, however, man can choose to obey or disobey it.

For a traditional Igbo man, the idea of natural law can adequately be communicated in relation to the legal significance of the 'Ala' the Earth Goddess. As a concept, Ala represents the totality of nature and to violate its law is to breach the natural law. In traditional Igbo parlance, natural law governs not only man but also other creatures. For instance, a cock that crows at odd hours is seen to have 'behaved' out of tune with the natural order and deserves to be killed. In the 
same manner, the dog must not eat the hen's eggs, nor the goat jump the roof. Neither should a snake swallow another, and so on. Thus, any violation of the natural law or law of nature either by man or other creatures carries grave consequences in Igbo traditional society.

From the above considerations, there is a thread of Aryana connecting the ideas of Divine Law, natural law, and moral law as they relate to man, namely, rationality. Hence, moral law understood as the natural law, which regulates rational human conduct, is latent in traditional Igbo thought. But moral law conceived as distinct from the divine or the natural law, and taken merely to be set of rules designed to direct man's conduct in society is completely alien to Igbo thought. Morality and religion overlap in traditional Igbo mindset. There is no such thing as morality within the confines of reasons alone which possibility in western ethics has been argued by the Enlightenment philosopher Kant. In a typical Igbo society, an act is bad either because it offends God or the ancestors or because it is contrary to Omenala (law and customs of the land). In this sense, omenala becomes the 'grundnorm', to use the language of Kelson, after which the validity and legitimacy of every other law and norm must be determined.

\section{Human Positive Laws}

Human positive laws occupy the next position in the hierarchy of Igbo laws. The Igbo people make laws on a wide range of subjects ranging from the economic, social and to political matters. Okafor observes that "though the Igbo do not have a permanent legislative body or a specialized legal institution with powers to make laws, laws are nevertheless made by an ad hoc general assembly, oha, which is in fact an all purpose assembly" 26 . On economic matters, laws can be made in respect of the use of the market places, ownership and control of certain economic trees and common natural resources (res commune) such as lakes and streams that provide fishes for home consumption and for the market. On the 
social aspect, laws can be made to give social directives on, for instance, the use and maintenance of public social facilities like roads, village squares, springs, etc. Laws can equally be made in order to ensure security of lives and property. Moreover, there are laws that relate to political issues especially to govern the political and diplomatic relationship between one village or town and another. For instance, laws forbidding citizens of a particular town from attending the market of another for political reasons abound. Boundary disputes, molestation or even killing of a member of one group by another and so on are common causes of breakdown in diplomatic ties between towns. Yet it is not only new laws that are made to meet the demands of changing socio-economic situations, but also old laws are subject to amendment or outright abrogation and repeal if they have outlived their usefulness.

At this juncture, it might be helpful to delineate the essential features of Igbo positive laws with a view to highlighting their profound values. First and foremost, the Igbo positive laws carry stamp of legitimacy. According to Farrar and Dugdale, legitimacy as a concept is longer limited to its Latin origin as meaning conforming with law or legality, but has now been extended to cover not only conformity with valid reasoning but also the possession of some extra quality of authenticity and genuineness. ${ }^{27}$ In other words, legitimacy of law, includes the issue of whether or not a piece of legislation proceeded from the right authoritative source for it to acquire the force of law.

In Igbo traditional society, legitimacy of laws is evident from the rigorous legislative process through which a bill must pass before it is declared and adopted as law. Although there is no formal and permanent legislature, laws are not arbitrarily made in traditional Igbo country. Certainly, the legislative authority vests in the Oha, the village general assembly, from which the legitimacy of any human law derives. All adult male members are eligible to be part of the assembly and have right to be heard. In general session, a legislative move (or what we today call bills) can be initiated by anybody or group after which the matter is thrown open for discussion. After the general assembly must have deliberated on the issue, the heads from each lineage in the village (paterfamiliae) retire for a "close session" (izuzu). Often, the participation in this 
consultative session is reserved only to men with high esteem and good moral reputation and having sufficient wisdom to discern the direction of public opinion. After the izuzu session, the decision, or say, suggestion is announced to the general assembly, whose acceptance or endorsement of the decision is necessary for the bill to become a law. This is followed by the ritual endorsement of the law by the $o f o^{28}$ ceremony according to which the ofo holders strike the ofo on the ground for four times to which the "Oha" responds "ise" or "iha" meaning "let it be so". No doubt, the ofo ritualism is for a divine ratification and committing of the laws into the hands of the Ala, the Earth Goddess.

Secondly, the Igbo human positive laws are ordinances of reason. Although Onyeocha argues that Igbo laws and rules appeal more to the head rather than to the intellect, and that their validity depends not so much on their ability to persuade the mind as in their functionality in maintaining order in the community for which he describes them as intuitionist, yet he believes that the laws are not irrational. ${ }^{29}$ Hence, the making of an unreasonable law does not have room in Igbo legislative system. This stems from the rigorous and republican procedure attendant to law making as we noted above. Thus, Igbo laws are not the product of reason of one individual as in autocratic states, nor that of a group of people as in aristocratic system, nor even that of the so-called representatives of the people as in modern democratic structures. The Igbo "ohacratic" system is akin to what obtained in the Greek city-states when direct democracy thrived. Hence, Igbo laws are fair, just, honest and observable when comprehensively considered. A good instance can be made with the 'market day law.'

The market day law forbids people from going to farms on a market day. Viewed from narrow perspectives, it would seem that this law is antithetical to people's fundamental right of movement and right to choose freely from a set of alternative legitimate economic activities. But when it is comprehensively considered that the Igbo village economy depends largely on what it can produce and sell, the rationality and the soundness of the law would be glaring. There is no doubt that the 'market' is the only medium for all local economic activities and the major source through which the village obtains its "foreign exchange". Again, the volume of 
business activities in any given market depends on the population of the market. Therefore, the raison d'etre of the market day law is to ensure that people turn out in large numbers for the market. This is particularly necessary as when a village loses its market due to poor attendance, its economy is put in jeopardy and this is followed by a series of economic consequences capitulating in serious socioeconomic distress. Thus, the law is quite reasonable.

Thirdly, Igbo human positive laws must be promulgated in order to have a binding effect. Promulgation means bringing a particular law to the notice of the public for a law that is not know to the generality of the Igbo village public may be regarded as nonexistent. Unlike in the English-influenced system, a law is not regarded as promulgated in Igbo nation merely because it has been gazetted. This is largely due to lack of literary culture in the traditional society. Two efficient methods of promulgation have been identified by Okafor. ${ }^{30}$ One is through the agency of the traditional town crier who is expressly commissioned to bring the law to the notice of the public. The other method is promulgation by the paterfamiliae of the respective families. It can be reminisced that legislative process takes place during occasional meetings when practically all adult male members of the village are in attendance. Thus, all the umunna are virtually represented by their family heads (paterfamiliae). The implication is that after the making of the law and the consequent ratification with the ofo, it becomes the civic duty of the family heads to bring the new law to the notice of their respective family members and ensure that they are obeyed. In the light of the above considerations, in Igbo society, once a law is not sufficiently promulgated, the common law principle of ignorantia juris neminat excusat (ignorance of the law is not an excuse) does not apply. Non-cupable ignorance can therefore be a formidable defence in any event. Though unwritten and 'unpublished', Igbo laws ought to be due promulgated in order to be binding.

Fourthly, the goal of Igbo positive laws is the common good. Cutting across individual or sectional interests, Igbo laws do not include retrospective law and ad hominem laws as found in some military legislation in Nigeria. ${ }^{31}$ The reason is simple. Since in the legislative stage all families are represented in the deliberation, consideration and adoption of bills prior to ratification as laws, it 
would be hard to come by any law that is not solely made in the interest of the common good.

Finally, the Igbo positive laws must be in conformity with the Igbo custom (Omenala). In Igbo parlance, "Omenala" or "Omenani" is a word loosely used to cover the Igbo laws and customs, traditions, etiquette, religion and morality. Hence, Mbonu Ojike calls the Igbo natural religion "Omenala"32 and for O'Donnell, "Igbo language has no special word for religion",33. The effect is that religion is part of the "Omenani". Okere evocatively refers to what he calls "Omereala" meaning literally, common practices in the sense of being permissible and normal and authentically valid in the society. ${ }^{34}$ Therefore for a practice to become an Omenana (or Omenani, Omenala, Omereala), its commonness or frequency must not be in doubt. One incident of it does not make it an Omenana. It must be imbued with constancy or in the scholastic language, a habitus. That is why a freak incident does not become rule of practice until it persists for a year and thereby enjoys general acceptability. This is articulated in the Igbo maxim "Omenenu gbaa afo o buruzia Omenana". Igbo human positive laws must therefore, for validity, conform to the omenani which represents though roughly, the 'constitution of the land.' Omenani is thus the yardstick for the validity of not only laws but also of all practices. It is the "norma normans non normata" (the norming norm that is not normed by any norm). Because omenani was not created by the conscious effort of any body, it approximates more to Hans Kelson's concept of the grundnorm that is not traceable to any law making body, than to modern constitutions which, though regarded as supreme, are nonetheless made positively by human beings. The conformity of Igbo positive laws with the omenani is therefore a safeguard against, inter alia, the enactment of immoral laws as there is no separation between law and morality in Igbo jurisprudence.

A profound look at the above analyses of the Igbo human positive laws would reveal that apart from the last feature, Igbo view of positive law is synchronous with Aquinas' definition of law as "the ordinance of reason for the common good promulgated by he who has the care of the community". ${ }^{34}$ Hence, the Igbo positive laws are reasonable, and for the common good. They are promulgated and are made by the 'Oha', the carers of the community, for the 
achievement of the common goal. In Igbo society, laws are not stumbling blocks but rules and regulations designed to preserve the peace, harmony and security of the community at large. At the event of administration of justice, the spirit of the law rather than its letters are sought and enforced. Technicalities play no leading role and the objective is to arrive at substantial justice. Generally in Igbo country, laws, morality, custom, religion, culture form a continuum. In what follows now, we shall inquire into the issue of crime and punishment in the administration of criminal justice in Igbo society.

\section{Crime and Punishment in Criminal Justice Administration in Igbo Society}

Questions of crime and punishment were purposely left out in the above discourse of traditional Igbo legal system. This is obviously to enable us focus on the twin issues which constitute the main subject matter of this paper. However, result of this study would be a distillation from a monolithic and comprehensive worldview in which crime and punishment just as so many other issues, have not only legal but also moral, religious, social and cultural significance. It is therefore only for the sake of convenience that we are approaching the present discussion under a separate head. What then are crimes in Igbo society and how are they detected? In criminal justice dispensation, how does the Igbo court arrive at a finding of guilt? What are the punishments to be meted on the offenders upon conviction in the relevant situations?

Our study above shows that there are various sources of Igbo laws, nay, Igbo criminal laws. Thus, there are divine criminal laws and human criminal laws. We do not share the view of Okafor who in this regard see the breach of only the divine laws as offences or crimes. Okafor argues that "only the violation of the divine law, which violation is held as ' $n s o$ ' or 'alu' could be regarded as a criminal offence, to use western legal term". ${ }^{35}$ There is no gainsaying that in criminal law, the words 'offence' and 'crime' are synonymous. Using the term 'criminal offence' would amount to one being unnecessarily tautologous. Although in Igbo parlance, crimes are not, as in common law, classified into felonies, misdemeanours, or simple offences, yet some crimes are more serious than others, and which seriousness depends on the legal 
framework that created the crime. Perhaps, it is because of the divine origin and thus more heinous nature of some misbehaviours that Okafor regards them as "criminal offences" in exclusion of others. But according to Oxford Advanced Learner's Dictionary ${ }^{36}$, a crime is "an activity that involves breaking of law", "an illegal act or activity that can be punished by law", or "an act that is immoral or a big mistake". Certainly, all these shades of meaning coincidentally underscore the Igbo understanding of crime. In Igbo thought, a crime is really an act that breaks the law (divine or human) and is punishable by law. And because there is no clear cut distinction between crime and morals, a criminal act is invariably an immoral act. Therefore, it would be reductionism for Okafor to restrict the list of "criminal offences" to violations against the divine laws (abominations, taboos, nso, or alu). But on another breath, he seems to agree with Green that there are two main classes of offences, those that are ' $n s o$ ' and those that are not ${ }^{37}$. Green refers to the former as taboos and to the latter as natural offences ${ }^{38}$. Therefore, Okafor needs to put his position straight on the issue of what constitutes crime in Igbo justice system. Although under the common law tradition, it is the law that says which act is a crime as distinguished from civil wrongs, and does not bother to give an essential definition of crime, yet in Igbo enclave many moral violations of divine and human laws are regarded as crimes.

However that may be, different scholars have tried to outline some of the items that constitute offences in Igbo justice system. Professor Ilogu puts together a set of twenty-four items which makes up what he calls "Igbo traditional moral code" 39 . It may not be necessary and convenient to adumbrate verbatim this set of twenty four items. But suffice it to say that Ilogu's code contains items that disrupt the natural order of things and occasions cosmic and not merely societal disharmony. It covers both the human and nonhuman acts. In the latter case, the issue of criminal responsibility is not considered at all. For instance, the act of a cock crowing at an awkward time in the night or a hen crowing like a cock, the act of a woman giving birth to twins, the act of a baby delivered "feet-first" rather than "head-first", the act of an infant cutting the upper teeth first $^{40}$, etc are acts clearly regarded as immoral or criminal without any consideration of the impossibility of criminal liability on the part 
of the "culprits". Many of the code items, however, are clearly human acts such as homicides, incest, suicide, poisoning someone with the intent to take his or her life, willful arson, theft of domestic fowls especially hen or her hatching pot where she can easily be taken along with her eggs, theft of any kind committed by an ozo titled man, adultery by a wife (not by a husband), secretly altering land boundaries especially during the night, divulging the identity of the masquerade especially if the offender is a woman, a woman breaking confinement by cooking and serving meals during her menstrual period especially if the husband is an ozo titled man, deliberately killing or eating any totem animal, deliberately cutting the succulent tendrils of yams in another's farm, a widow having sexual relationships while still in the period of mourning her dead husband, a husband deliberately breaking or throwing away his wife's utensils, etc. It is observed that all the offences in this category are within the control of man as he is free to do or not to do them unlike those mentioned earlier which are completely outside human control.

Besides, it seems that some of the code items are discriminatory when viewed through the western socio-psychological binoculars. Yet the Igbo traditional thought offers some justifications for them. Instances of these offences include adultery by a wife, a wife throwing her husband down on the ground in the course of a domestic scuffle, a woman climbing a palm tree or kola nut tree especially if she does so with a climbing belt (ete or akpi), etc. While all these are discriminatory against women and one would ask why are they not also applicable to men, the offence of a freeborn (diala) spending nights or having sexual relation with $\mathrm{Osu}$ (slave dedicated to a deity) is also generally discriminatory. It is equally regarded as an offence to die a "bad death", that is, death resulting from an infectious disease like leprosy or small pox, or dying within one year after having sworn to an oath.

Be that as it may, there is no gainsaying that the list of offences in Ilogu's traditional ethical code is not exhaustive. Certainly, what constitutes offences in traditional Igbo society cannot be restricted to such a short list. The list is expected to be widened as morality, criminality, illegality, religion dovetail into one another. However, 
we shall focus on some traditional Igbo crimes and see how criminal justice is administered in relation thereto.

Let us take the case of homicide (murder). This is regarded as a very grievous offence not only against the society but also a violation of divine law. Life is believed to have come from God. Therefore, any shedding of another's blood under any circumstance is an abomination (alu). Even in times of war, those who participated especially those who killed in the war are expected to undergo the ceremony of ritual cleansing (ikwa aka ochu). Thus, if a villager kills another man, the murderer is expected to hang himself for, according to Okafor, "there is no provision for the public or private execution of murderer in Igboland." 42 Okafor further describes the nature of penalty against a murderer:

The villagers may nonetheless exert serious psychological and social pressure on the murderer but cannot go beyond that. If the murderer has fled, his family must also flee, and their property is confiscated. Whenever the murderer is caught, he will be made to hang himself to enable the umu okpu (daughters of the land) perform their cleansing rites, izachapu ntu ochu (sweeping away the ashes of murder... Failure to perform these rites has consequences which are dreadedby the villagers. ${ }^{43}$

There is no doubt that Okafor is referring to the murder of a kinsman by a kinsman. Certainly the case would be different if the murderer is from another village. The scenario is adequately created in Achebe's Things Fall Apart. ${ }^{44}$ A woman the wife of Ogbuefi Udo from the tribe of Umuofia in Igboland was murdered for no just reason by people from the neighbouring tribe of Mbano. On account of this, a general meeting of all the men of the tribe was summoned during which one of their most powerful orators, Ogbuefi Ezudo, addressed them on the incident:

'Those sons of wild animals' have dared to murder a daughter of Umuofia'. The crowd, now full of anger and thirst for justice, had to deliberate on the best 
means to realize justice. At the end of their deliberations, an ultimatum was immediately dispatched to Mbano asking them to choose war or offer a young man and a virgin as compensation.

Okonkwo was delegated by his townsmen to carry across the message to Mbano. Achebe records that Okonkwo "returned from his mission two days later with a young lad of fifteen and a young virgin". ${ }^{45}$ Thus, in the execution of retributive justice, the young virgin (perhaps the daughter of one of the accomplices in the murder) was given to Ogbuefi Ezeudo as compensation for his murdered wife, while the young boy Ikemefuna innocent though he is, was murdered on the community's wish. Even in the case of accidental killing, heavy compensation is paid not excluding getting a wife for the diseased family (inuchi nwanyi). It is thus observed that in the picture painted above, punishment is both compensatory and expiatory in nature. This takes care of both the human and divine disharmony created by the offence of murder. In the case of murder by a kinsman, it seems it is sufficient for the murderer to hang himself and to serve for the purpose of expiation and retribution.

It is observed that in the two sets of homicide cases above, expiatory sacrifices to pacify the gods are involved. This is because homicide of any kind is, first and foremost, an offence against the gods. Ordinarily, it is not usual for the Igbo to put a murderer on trial nor to punish him himself for he believes that any case involving a human life is essentially outside human jurisdiction. That is why the murderer is expected or pressurized to hang himself. The situation would be different if there is no material evidence to prove the suspect guilty of the offence especially in the cases of death by spiritual poisoning or other occult means. Under this dispensation, the suspect would be required to swear before a powerful tutelary deity that he is innocent of the accusation. Hence, it is the accused who initiates the move to prove his innocence. This is the reverse of the common law culture where the onus is on the prosecution to prove beyond reasonable doubt the guilt of the accused. ${ }^{46}$ It is normally believed that if by the end of the year or two after the oath swearing and no harm befalls the accused, then he would have been 
acquitted by the supernatural tribune. Otherwise 'Ani' and the ancestors would either kill him or inflict some grave punishment perhaps in form of blindness, small pox, a mass death of the relations of the accused, or punishment deferred much later in the accused's life, or even be transferred to his children. An alternative to oath swearing would be to make the suspect drink the bath water of the diseased in order to prove his innocence and the effect would be the same as in swearing. The above procedure is the same for other offences against the gods (abominations) such as incest, which is a taboo is defined as having intercourse with a person one cannot marry by reason of their blood relationship. Often, offenders are sold into slavery as they are thought to have polluted the land. Yet another phenomenon associated with violations of the divine laws is "isa asisa" (confessions at death bed). Practically, the Igbos believe that notorious criminals responsible for the untimely death of other villagers either by poisoning, sorcery, magic or witchcraft must confess their awful crimes at death bed. The criminal usually dies after the confession directed, as it were, to nobody in particular. Generally, the Igbos believe that divine vengeance is inevitable and great misfortunes are thought to be God-sent punishments. Therefore, if a lightening strikes a man or his house, sudden death, or cases of one dying with a swollen stomach, etc, such situations are regarded as punishment for some hidden crimes committed by the victim.

The procedure would be different if the offence is one that is less grievous. Let us take the offence of theft. If a man steals from a kinsman and it is proved, the thief will be sternly warned and rebuked if the stolen property is trifle. If the property involved is of high value, the thief is tied up for days without food and if he was caught red-handed, he is carried about the village especially round the market square with the stolen property conspicuously tied around his neck while passers-by jeer, curse and spit on him. Later, the thief would be expected to make restriction. The punishment will be more severe if the stolen property is symbolic such as yams, hen and so on or if certain persons are the culprits such as titled men, elders, etc. Stealing from an outsider is even much more serious for the thief is detained until a substantial ransom is paid by his relatives apart from which in the former times, the culprit would be sold into slavery. In 
the case of suspicion, an appeal to the supernatural is made by which an oath is administered, for false accusation is equally grave and avoided.

Further, in the case of violation of laws against interpersonal relation, the procedure involves much of human agents. The injured party may first appeal to the head of the family of the offender or a body of village arbitrators. If this fails to reach an amicable settlement of the issue, the injured party may summon the Amala, a higher body than the former with close friends of the litigants in attendance. In the events of further failure, other institutions which may be appealed to include the age grade association, the Dibia fraternity, various title-taking societies, town union, mmanwu society, etc. When all these efforts fail, then as a final resort, a submission is made to the supernatural tribune in form of oath swearing. Punishments that can be meted in the cases of violation of human positive laws touching the common good of the society include ostracism, banishment, fines, forfeiture of valuable property, and so on.

A critical look at the above discourse would showcase the intricate and complex nature of traditional Igbo legal system in general and its criminal justice system in particular. Interwoven with religion, morality and spirituality, law, both divine and human, is aimed at not just social engineering but total integration of the entire aspect of human life. The human order, the cosmic order and the spiritual order are covered by the entire spectrum of a legal system. Any act, human or otherwise, that disrupts this integral harmony is viewed with consternation and attracts immediate redress. Punishment which ranges from verbal warning, fines, forfeitures, ostracism, banishment or even death, depending on the seriousness of the offence, is multifarious in purpose. Sometimes, it may be for the purpose of giving a fair desert (retribution) to the offender or for the reason of reforming him into becoming a better member of the society. Other reasons may include deterrence on the part of the offender or other future offenders, reparation as a result of committing the offence and to re-establish the harmony destabilized by the offence, or for the aim of incapacitating or removing the offender from the social group. Again, the Igbo judicial apparatuses involve the roles of human and divine personages. Methods of 
adjudication, trial by ordeal, and oath swearing are often employed in the findings of guilt. It now remains for us to examine the state of these practices in the light of the Nigerian legal system.

\section{Traditional Igbo Criminal Justice Vs Nigerian Legal System Today}

One of the greatest challenges to traditional Igbo criminal justice administration is constituted by some principles of Nigerian legal system. This is expected as much of Nigerian legal and judicial structures today are a British legacy as a result of the colonial enterprise. The result is that most of the values of the traditional systems received a knock on the head and in some cases outright abolition by a set-up that failed to undertake a disinterested cultural study of the traditional practices including the legal and judicial systems. No doubt, this colonial antipathy to traditional patterns spelt doom for the development of the justice system. In what immediately follows, we shall examine their implications for traditional Igbo criminal justice administration as it pertains to crime and punishment.

\section{Abolition of Customary Criminal Justice}

The post-independence legal system in Nigeria had as part of its agenda, the abolition of customary criminal law. Certainly, one of the important features of customary law generally is that the principles are unwritten and which feature provided the impetus for constitutional abolition of unwritten criminal law. Thus, section 22 (10) of the 1963 Republican Constitution provides that "no person shall be convicted of a criminal offence unless that offence is defined and the penalty therefor prescribed in a written law, except in contempt of court". With section 33(12) of the 1979 Constitution which is in pari materia with section 36(12) of the 1999 Constitution, even the safety guaranteed to unwritten contempt of court had been removed so that any crime and punishment must be as a result of a written law enacted by the appropriate legislative authority. Section 30(12) of the 1999 Constitution provides thus:

Subject as otherwise provided by this constitution, a person shall not be convicted of a criminal offence 
unless that offence is defined and the penalty therefor is prescribed in a written law; and in this subjection, a written law refers to an Act of the National Assembly or a Law of a State, or any subsidiary legislation or instrument under the provisions of a law.

There is no doubt that the immediate implication of the above constitutional provision for traditional Igbo criminal justice is that insofar as the Igbo criminal law and principles are not enacted into a written law by the appropriate legislative body, the continued implementation and administration of criminal justice would be clearly unconstitutional and illegal. The Nigerian courts have had the opportunity to make pronouncement on the provision. Hence, in Aoko v. Fagbemi, ${ }^{47}$ the court declined jurisdiction on a charge of adultery because adultery is not one of the offences in Criminal Code in the Southern part of Nigeria. The court maintained the same attitude in Udokwu v. Onugha. ${ }^{48}$

As if the above is not enough, section 36(4) (supra) provides that whenever any person is charged with a criminal offence, he shall, unless the charge is withdrawn, be entitled to a fair hearing in public within a reasonable time by a court or tribunal established by law." This provision has enormous implications for Igbo criminal justice system. First and foremost, it provides that the hearing must be conducted in public. This means that hearing should be in a public place and accessible by the members of the public, male and female. This is quite the opposite of what obtains in Igbo traditional criminal procedure in which hearing is done in camera as it is not accessible to the public. Attendance is restricted to the adult male members of the community rather than to the generality of the public. Secondly, the criminal trial, according to the provision, must take place in a court or tribunal established by law. The effect is that since the courts in question are those recognized by the Constitution expressly or by implication, such fora as the village assembly, town unions, masquerade societies, umunna, age grade, and so on by which traditional criminal justice is dispensed can at best be described as kangaroo courts in the eye of Nigerian criminal justice system which views them as unconstitutional, illegal, and lack jurisdiction. 


\section{Attitude to Spiritualism}

The Nigerian jurisprudence generally does not concern itself with matters bordering on spiritualism. Modeled after the British type court system, the adjudicatory parameters of the Nigerian courts are confined to issues and evidence adduced before it. But from our study above, it is crystal clear that the mainstay of Igbo traditional criminal justice system is an unwholesome involvement with the supernatural especially in more serious offences. Even in precolonial times in Nigeria, the fate of many spiritually-related criminal cases involving witchcraft, sorcery, talisman and spiritual poisoning was decided, albeit, negatively an account of the metaphysical nature of the issues canvassed. ${ }^{49}$ Besides, under the Criminal $\operatorname{Code}^{50}$, all forms of trial by ordeal, criminal charms, witchcraft issues, and Juju-related matters have been rendered unlawful which effects portend nothing but a show down for Igbo criminal and penal justice. Again, oath swearing in criminal matters, apart from its spiritualist character, has invariably been abolished together with the general abolition of customary criminal law. In civil justice where customary civil justice is still preserved under section 315 of the 1999 Constitution as part of the existing law, the practice of oath swearing is fraught with controversy as a result of conflicting court decisions. In Charles Ume v. Godfrey Okoronkwo \& $A$ An ${ }^{51}$ which involved a land dispute and in which in the traditional arbitration stage the plaintiff was required to swear on a juju to be produced by the first defendant, the supreme court per Ogbuagu JSC delivering the lead judgment held inter alia that oath taking was one of the methods of establishing the truth of a matter and was known to customary law and accepted by the parties." ${ }^{, 52}$ Similarly in Ofomata \& Ors v. Anoka ${ }^{53}$, Agbakoba J. held:

Oath taking is however a recognized and accepted form of proof existing in certain customary judicature. Oath may be sworn extra-judicial but as a mode of judicial proof ...it is therefore my view that the decision to swear an oath is not illegal although it may be obnoxious to Christian ethics.... 
Again, in Okere v. Nwoke ${ }^{54}$, the respondent admitted before the court the customs of settling dispute by oath-taking. The court later held that "the appellants having been led to take oath on the "Aka obibi juju" provided by the third defendant at great risk to their lives in the belief that the customary oath would settle the dispute, the respondents are entrapped by conduct from denying that appellants were thereby adjudged owners of the land, the latter having sworn the oath for over one year".

But in Iwuchukwu v. Anyanwu, ${ }^{55}$ Ndoma - Egba J.C.A. demonstrated his disapproval on the practice of oath taking in the settlement of disputes. He stated thus:

The belief of the learned trial judge that disputes are decided by swearing "juju" may be true as a matter of the past. In this century, that will be a retreat to trial by ordeal which is unthinkable any more than swearing any more than swearing "juju" as a method of proof. We cannot now reel back to superstitious fear and foreswear our religious faith.

In fact in Onwuanunkpa v. Onwuanunkpa ${ }^{56}$, the court condemned the arbitration practice that was based on oath taking as no arbitration at all.

In the same manner, Nwakoby, an expert in arbitration law in Nigeria argues that, in the light of modern civilization and the nature of jurisprudence in Nigeria today, practice of oath taking even in customary civil judicature should be deprecated. For him, the practice is not only fetish, barbaric, uncivilized but also outdated, obnoxious and anachronistic. He argues strongly that customary justice decision based on oath-taking is not final as the finality of it depends on the outcome of the oath or its resultant effect. He observes that this effect is often precarious as there are not only antidotes to oath taking (ndagbuiyi) but also that the medical condition and state of health of the oath-taker is not often ascertained prior to the taking of the oath. ${ }^{57}$ 
No doubt, the above controversy surrounding the practice of oath-taking has enormous implication on Igbo traditional justice system in which oath-taking plays an important role. Thus, the whole idea of finding of guilt, detection of crime, and the penal system as they relate to oath-taking rises and falls with the failure or success of the system.

\section{An Evaluation}

This paper has tried to examine, albeit briefly, the fundamental elements of traditional Igbo legal system. It has also traced from within it the methods of traditional criminal jurisprudence in all its aspects. Issues of crime and punishment were specifically focused on. A major fruit of this study is that this traditional justice system is existing in a society that is fast undergoing rapid socio-economic and political changes. But its greatest challenge is some principles of Nigerian legal system that abolished its practices in toto. In the light of the above considerations, what will be our response?

There is no gainsaying that one important feature of culture is that it is dynamic. Culture and traditions change as the socioeconomic and other needs of a society change. A legal system, nay, criminal justice system suited for that society would need to be evolved. No culture is a finished product. It therefore follows that both the Igbo culture and western legal culture must learn from each other. In the light of this need for the symbiosis, the following salient points need be taken into consideration. Firstly, the western colonial legal system need not see itself as superior to the Igbo and other Nigerian traditional systems. Instead of denigrating the local custom which attitude eventually led to the abolition of customary criminal justice system, it would have helped the local systems to throw away the bath water while retaining the baby. Such elements like trial by ordeal and adjudication involving the animals would have been jettisoned while still retaining the criminal justice system. It is no doubt in reaction to the need for customary justice system that many northern states recently clamoured for and re-adoption of the Sharia legal system which for a long time was regarded as part of native law and custom ${ }^{58}$. Yet the autochthononous governments could not help matters with regard to customary criminal justice. One would have thought that adjudication over criminal cases 
bordering on traditional sensibilities would be an issue of jurisdiction of customary courts.

Secondly, the idea of criminal justice as founded on a written code is quite pretentious in an oral-based culture such as those of many traditional enclaves in Nigeria even up till today. The domino effect is that most of the inquiries bugging the general traditional public are allowed to thrive because they have not been criminalized into a written law. A veritable alternative would have been the appropriate legislative authority standing tall to its responsibility by enacting the relevant misbehaviours into offences. But experience in Nigeria has shown that this ideal would be far from realized as the attitudes of many of the members of legislature are characterized by absenteeism, embezzlement, contract scam, and general lack of seriousness.

Thirdly, instead of staying away from spiritual-related cases, a better judicial attitude would have been to create courts that would be vested with jurisdiction on said matters. Composed by judges, learned, knowledgeable and disposed to spiritually related criminal cases, such courts would be in a position to resolve a lot of societal conflicts that bug the indigenous populace but which are treated with "judicial injustice" by our present crop of courts ${ }^{59}$.

Perhaps, the major problems with the Igbo traditional criminal justice system are the apparent discriminatory practices embedded in it. Administration by restriction to adult male members of the community, the all-to patriarchal and gerontocratic structure associated with it, and its general admixture and complexity are instances of those practices that need be subjected to critical scrutiny.

Finally, this paper suggests a deep and critical study of traditional practices. Instead of condemning the practices wholesale without due regard to the values intrinsic in them, the government should for the sake of those values establish commissions and centers for cultural studies in which relevant experts participate. In this way, our traditional values including those of crime and punishment would be deciphered, preserved and enhanced. 


\section{References}

1. Okonkwo, C.O. Criminal Law in Nigeria ${ }_{2}$ Spectrum Books Ltd., Ibadan, 2002, p. 28.

2. Section 36(12) of the Constitution of the Federal Republic of Nigeria (CFRN) 1999

3. Section 36(8) of C.F.R.N

4. Instances include Dostoevsky's Crime and Punishment $\left(19^{\text {th }}\right.$ century), Cesare Beccaria's On Crimes and Punishments (1764), etc. Others have added just a word to the two concepts for their titles eg. Gibb's Crime, Punishment and Deterrence (1975), Ten's Crime, Guilt and Punishment (1987), Journal of Criminal Law's "Crime, Punishment and Personality" (1976), etc.

5. Scholars are not agreed on what justifies punishment. So many theories abound: deterrence, retribution, reformation, reparation, expiation, education, incapacitation, etc (see P.J. Fitzgerald, Salmond on Jurisprudence,_N.M Tripathi Private Ltd. P 4-105; J.M. Elegido, Jurisprudence, Spectrum Books Ibadan, 1994, 213 - 226).

6. Cf S. Ottenberg, "Ibo Receptivity to Change" in W.R. Bascom and M.J. Herskovits(eds), Continuity and Change in African cultures, The University of Chicago Press, Chicago, 1959, 103-143.

The Igbo receptivity to change is often contrasted with the Pakot resistance to change. See H.K. Schneider, "Pakot Resistance to Change" in W.R. Bascom and M.J. Herskovits (eds), OP. Cit. $144-167$.

7. C. Kraft, Christianity and Culture, Orbis Books, New York, 1979, 53.

8. F. U. Okafor, Igbo Philosophy of Law, Fourth Dimension Publ. Co. Ltd. 1992, 13.

9. E. Onuoha, Four Contrasting Worldviews,_Empress Publ. Co. Ltd. 1987, 26.

9. J. Oguejiofor argues that 'context - dependent' nature of a worldview explains the wide variations and the narrow nuances that are comparative features of different worldviews (cf Oguejiofor "African Worldview..." in Bigard Theological Studies, Vol. 24. No. 1, 28.

$10 . \quad$ T.U. Nwala, Igbo Philosophy, Literamed Publications Nig. Ltd. 1987, 28.

11.

F.A. Arinze, Sacrifice in Ibo Religion, Ibadan University Ibadan, 1970, 9. Abanuka argues that in Igbo society, there are other names of God which are borrowed from other tribes: Osebuluwa (Edo), Obasi (Efik), Olisa (Yoruba) (Cf B. Abanuka, Philosophy and Igbo World, Snaap Press, Enugu, 2004, 2) 
12.

F.A. Arinze, Op. cit, 17.

13. E.G. Parrinder, West African Religion, Epworth Press, London, 1949, 125.

14. A.O. Onyeneke, The Dead Among the Living. Masquerades in Igbo Society, Asele Institute, Nimo, 1987.

15. E.I. Metuh, African Religious in Western Conceptual Scheme Imico Press, Jos, 1985, 109.

16. J.S. Mbiti, African Religions and Philosophy, Heinemann, 1977, 92.

17. Cf. J. Oguejiofor, "Miracle Christianity" in The Nigerian Journal of Theology, vol. 15, 2001, 40. C. Mbaegbu however argues that even though "man is important and indeed central in Igbo worldview, he is by no means the measure of all things." (See C. Mbaegbu, Ultimate Being in Igbo Ontology, An Unpublished Doctoral Thesis on African Philosophy, University of Nigeria Nsukka, 1997, 138).

18. M.N. Nkemnkia, African Vitalogy: A Step Forward in African Thinking, Pauline's Publication Africa, Niarobi, 1999.

19. Names such as "Nduka" (Life is greater), "Ndubuisi" (Life is first) and proverbs such as "Ndu kariri ihe eji a zo ya" (Life is greater than what was spent to sustain it), "A ghalu ndu kpaa aku, onye ilo erie" (If life is lost due to inordinate pursuit of material wealth, the enemy takes the wealth) are quite illustrative (cf I.K.E. Oraegbunam, "Towards an Afro-Christian Ethics of life" in The Sign, Vol. 4, No. 7, June 1999 - June $2000,37-38)$.

20.

Ibid., 37

21.

Cf S. N. C. Obi, Customary Law Manual, for instance.

22.

M.M. Green, Ibo Village Affairs, Frederick A. Praeger

Publishers, New York, 1904, 9.

23. F.U. Okafor, Op. Cit., 35. Though Izu Onyeocha agrees with Okafor that these principles are not traceable to any particular individual in terms of their history and origin, yet he believes that they did not just spring up. He argues that their thought processes behind their enacting and the first moments of their existence are lost to records because of the preliterate environment that prevailed at the time they were born (See Izu M. Onyeocha, "Sin, Guilt and Sanctions in Igbo Ethics" in Journal of Inculturation Theology, Vol. 8. No. 1, April 2006, P 63-64).

24.

See D. Lloyd, The Idea of Law, Penguin Books, England, $1991,70-94$.

25.

Okafor, Op. Cit., 52, 60 - 62

$26 . \quad$ J.H. Farrah and A.M. Dugdale, Introduction to Legal Method_( ${ }^{\text {rd }}$ Ed. $)$, Sweet \& Maxwell, 1990, 11.

$27 . \quad$ Okafor, Op. Cit, 52. 
28.

I.M. Onyeocha, Art. Cit, 67.

29. Okafor, Op. Cit, 56.

30. Eg. Decree 28 of 1970. Cf Lakanmi v A.G. West (1971) 1

U.I.R. 201.

31.

O. Mbonu, My Africa, Doubleday, New York, 1946, 154

-155 .

32. W.O' Donnell, Religion and Morality among the Igbo of Southern Nigeria, London, 1931, 57.

33.

Thomas Aquinas, Summa Theologica, Ia IIae, q. 90, a.4.

34. Okafor, Op. Cit, 39.

35.

A.S. Hornby, (ed.), Oxford Advanced Learners'

Dictionary (6 ${ }^{\text {th }}$ Ed.), Oxford University. Press, Oxford, 2000, 276.

36. Okafor, $\mathrm{Op}$. Cit, 7.

37. M.M. Green. Op. Cit., 99.

38. E. Ilogu, Christianity and Igbo Culture,_E.J. Brill, Leiden, $1987,125-126$.

39.

Items $21-24$ of the code.

40.

For instance, prohibitions _against a woman climbing trees is justified when it is considered that it will be offensive to the beholder because the anatomical structure of the female body was considered ill suited to the hazardous activity of tree climbing. Besides, given the usual mode of dress for female, it would lead to indecent exposures of her anatomy (See I. Onyeocha, Art Cit. 68 - 70).

41.

Okafor, Op. Cit, 35,

42.

Ibid, $35-36$.

43.

C. Achebe, Things Fall Apart, Heinemann, London, 1981.

44.

Ibid.

45. Cf section 135(1) \& 135(2) of Nigerian Evidence Act, cap E14, Laws of the Federation of Nigeria, 2004.

46.

47. (1961) 1 All N.LR. 400.

48. (1963) 7 EN. L.R.1.

Egbuaba Odo (1938) 4 W.A.C.A. 71; Akerele v. I.G.P. (1955) 21 N.L.R. 37; West v. Police (1952) 20 N.L.R. 71; R.V. Udo Aka Eka Obong (1947) 12 W.A.C.A 139; Gadam V. R (1954) 14 W.A.C.A. 442; Rv. Konkomba (1952) 14 W.A.C.A 236; Aiguokhian v. The State (2004) 7 NWLR 566; Re-Opekun (2002) 6 NWLR, 583, etc. For details, see I.K.E. Oraegbunam, "A Philosophical Critique of Some Judicial Attitudes to Juju - Related Crimes in Nigeria" in Essence, No 2, 2005, $184-203$.

49.

Cf sections 207 to 213 of the Criminal Code, cap C. 38, Laws of the Federation of Nigeria, 2004. 
50.

(1991) 12 SCNJ, 404.

51.

Ibid.

52.

(1974)4 ECSLR, 51.

53.

(1991) 8 NWLR (pt 209) 311.

54.

(1993) 8 NWLR (pt 311) 307 at 323.

55. (1993) 8 NWLR (pt 310) 186.

56.

G.C. Nwakoby, The Law and Practice of Commercial Arbitration in Nigeria, Iyke Ventures Production, Enugu, 2004, 87.

57. $\quad$ Cf Section 3(2) of Penal Code Law; See also M.C. Okany, Fourth Direction Publishers Enugu, 1984, 39. A distinction was however made between Customary law and Sharia law by the Supreme Court per Wali JSC in Alkamawa. v. Alhaji Bello \& Anor (1986 The Role of Customary Courts in Nigeria,) 6 S.C.N.J, 127 at 136.

58.

Cf I.K.E. Oraegbunam, Art Cit, 199 - 200. 